\title{
A 3-Mb High-Resolution BAC/PAC Contig of 12q22 Encompassing the 830-kb Consensus Minimal Deletion in Male Germ Cell Tumors
}

\author{
Vundavalli V.V.S. Murty, ${ }^{1,5}$ Kate Montgomery, ${ }^{2}$ Shipra Dutta, ${ }^{1}$ Shashi Bala, ${ }^{1}$ \\ Beatrice Renault, ${ }^{2}$ George J. Bosl, ${ }^{3}$ Raju Kucherlapati, ${ }^{2}$ and Raju S.K. Chaganti ${ }^{4}$ \\ ${ }^{1}$ Department of Pathology, College of Physicians \& Surgeons of Columbia University, New York, New York 10032 USA; \\ ${ }^{2}$ Department of Molecular Genetics, Albert Einstein College of Medicine, Bronx, New York 10461 USA; ${ }^{3}$ Department of \\ Medicine, and ${ }^{4}$ Laboratory of Cancer Genetics \& Department of Human Genetics, Memorial Sloan-Kettering Cancer Center, \\ New York, New York 10021 USA
}

\begin{abstract}
Cytogenetic and molecular genetic analyses have shown that the $12 q 22$ region is recurrently deleted in male germ cell tumors (GCTs), suggesting that this site may harbor a tumor suppressor gene (TSG). Previous loss of heterozygosity $(\mathrm{LOH})$ analyses identified a consensus minimal deleted region between the markers D12S377 and D12S296, and a YAC clone contig covering the region was generated. Here, we describe a high-resolution sequence-ready physical map of this contig covering a 3-Mb region. The map comprised of 52 cosmids, 49 PACs, and 168 BACs that were anchored to the previous YAC contig; 99 polymorphic, nonpolymorphic, EST, and gene-based markers are now placed on this map in a unique order. Of these, 61 markers were isolated in the present study, including one that was polymorphic. In addition, we have narrowed the minimal deletion to $\sim 830 \mathrm{~kb}$ between D12S1716 (proximal) and P382A8-AG (distal) by LOH analysis of 108 normal-tumor DNAs from GCT patients using 21 polymorphic STSs. These physical and deletion maps should prove useful for identification of the candidate TSG in GCTs, provide framework to generate complete DNA sequence, and ultimately generate a gene map of this segment of the chromosome 12.
\end{abstract}

[The sequence data described in this paper have been submitted to the Genome Survey Sequence under accession nos. AQ254896-AQ254955 and AQ269251-AQ269266. Online supplementary material is available at http: / / www.genome.org]

Recurrent cytogenetic aberrations affecting both the short and the long arms of chromosome 12 are a characteristic feature of male germ cell tumors (GCTs) (Chaganti et al. 1996). Extensive cytogenetic and molecular genetic studies of male GCTs identified genetic alterations on chromosome 12q. Cytogenetic studies demonstrated subregional deletions or monosomy of 12q in a high proportion of cases (Murty et al. 1990; Samaniego et al. 1990; Rodriguez et al. 1992). At the molecular genetic level, restriction fragment length polymorphism (RFLP) analysis identified loss of heterozygosity (LOH) at two sites, 12q13 and 12q22, suggesting the presence of at least two candidate tumor suppressor genes (TSGs) (Murty et al. 1992). LOH analysis of 12 q22 revealed allelic loss in $51 \%$ of tumors and a homozygous deletion in one tumor further supported this view (Murty et al. 1992). The minimal deleted region was subsequently localized between the markers D12S1716 and D12S346 (Murty et al. 1996). We also constructed a detailed physical map of the

${ }^{5}$ Corresponding author.

E-MAIL vvm2@columbia.edu; FAX (212) 305-5498. region by identifying contiguous mega YAC clones covering the minimal deleted region and generated a radiation hybrid map (Murty et al. 1996). To facilitate the isolation of candidate TSG(s), in the present study, we developed a 3-Mb sequence-ready contig map consisting of BACs, PACs, and cosmids of the region of $12 q 22$ that includes the minimal deletion. We were further able to narrow the deletion interval to an 830$\mathrm{kb}$ region by $\mathrm{LOH}$ analysis of additional normal-tumor paired DNAs using new polymorphic markers. This study represents generation and mapping of 61 new STSs, including one polymorphic marker, as well as placing of several known ESTs and genes in the contig. The new map that we present will comprise the framework to generate a complete DNA sequence of the region and forms a basis for identification of the candidate TSG(s) in GCT.

\section{RESULTS}

Construction of a 3-Mb BAC, PAC, and Cosmid Contig at 12q22

We previously generated a YAC contig map defined by 
the interval D12S101 proximally and D12S346 distally. This map consisted of 53 clones and included deleted region onto which 25 STS markers were ordered (Murty et al. 1996). These STSs served as the framework in generating the cosmid, PAC, and BAC clone contig described here. Initial screening was performed with 10 known nonpolymorphic STSs and STSs designed from the published sequences of polymorphic markers (GCT8BO7, D12S1300, D12S1671, D12S296) (Murty et al. 1996; Kucherlapati et al. 1997). This screening resulted in the isolation of eight clone clusters of cosmids, PACs, and BACs anchored to the framework map with large gaps between them. In the initial phase of contig construction PAC and BAC clones were more successfully linked with adjacent loci than cosmids. Therefore, subsequent screening and contig expansion was restricted to PAC and BAC libraries. A bidirectional chromosome walk was initiated from these clone islands in which appropriate clone ends were sequenced, and new STSs, which were used as probes to rescreen libraries, were generated. New clones identified in this manner were placed on the map by PCR analyses. After several rounds of screening, this strategy allowed us to generate a complete high-density map of the region consisting of cosmids, PACs, and BACs (Fig. 1). A total of 269 clones (52 cosmids, 49 PACs, and 168 BACs) were placed in the present contig, which span a 4-cM genetic distance (Dib et al. 1996) between SHGC-33859 (HAL) (proximal) and D12S1100 (distal) (Fig. 1). To complete the contig by linking these clones, sequences from 76 cosmid, PAC, and BAC ends were generated (sequence data submitted to Genome Survey Sequence; accession nos. AQ254896-AQ254955, AQ269251AQ269266). This sequence information enabled us to design primers for new STSs, and a total of 61 STSs were mapped back to the contig (Table 1; Fig. 1). These STSs included a dinucleotide polymorphic marker, P382A8$A G$. All of the newly generated STSs were also mapped by STS-content analysis onto the YAC clones in the contig. This enabled us to anchor cosmid, PAC, and $\mathrm{BAC}$ clones to the YAC contig and the genetic map. The clone coverage obtained for the markers in the map ranged between 2 (D12S1082) and 28 (D12S1218E). Eleven clones containing D12S1100 at the extreme telomeric end of the YAC contig have been included although they were not connected with the PAC/BAC contig.

\section{Mapping of ESTs and Genes to 12q22 Physical Map}

A total of 36 ESTs within the genetic interval of 101$106 \mathrm{cM}$ were identified from databases of human physical and transcript maps. The ESTs were first PCR amplified on pooled YAC clones covering the minimal tiling path; however, only 13 of them mapped within the YAC contig. The individual YAC, BAC, PAC, and cosmid clones were then analyzed by PCR for STS con- tent using these 13 ESTs to determine their precise map positions (Fig. 1). Of these, one EST (WI-17759) was mapped within the previously defined minimal deleted region in GCTs (Murty et al. 1996) and the remaining were mapped outside. Among the 13 ESTs, eight represented five known genes. These included histidine ammonia-lyase (HAL, SHGC-33859), ETSdomain protein ELK3 (ELK3/Z36715), human thymopoietin (TMPO, WI-11271), phosphate carrier mitochondrial (PHC, D29485) and apoptotic protease activating factor (APAF1). The HAL, ELK3 (NET3), PHC, and TMPO genes were previously mapped in the YAC contig (Murty et al. 1996; Kucherlapati et al. 1997). The TMPO gene was previously mapped to $12 \mathrm{q} 22$ by FISH (Harris et al. 1995). APAF1 was identified through BLAST search of P373G19-T7 end. The HAL and ELK3 genes were mapped proximal, whereas TMPO, PHC, and APAF1 were mapped distal to the consensusdeleted region (Fig. 1).

\section{Refinement of the Minimal Deleted Region Between D12S1716 and P382A8-AG}

Expecting that new polymorphic markers might help narrow the minimal deletion further, we identified six dinucleotide repeats from the BAC, PAC, and cosmid end sequences. We designed primers flanking a dinucelotide $(\mathrm{AG})_{n}$ repeat from P382A8 clone end (accession no. AQ254947) that was mapped in the previously identified region of minimal deletion. We were unable to design primers from others because of flanking Alu repeats. On testing of a panel of 91 normal DNAs, P382A8-AG exhibited heterozygosity in 76 (83\%). We previously defined the minimal deleted region between the markers D12S1716 proximally and D12S346 distally with an estimated size of $1.7 \mathrm{Mb}$ based on $\mathrm{LOH}$ analysis of 67 normal-tumor GCT DNAs using 18 polymorphic markers. These tumors were now analyzed for LOH with three additional markers (GCT8BO7, D12S1671, P382A8-AG) (Table 2). In the present study, we also analyzed an additional panel of 41 normaltumor GCT DNAs for $\mathrm{LOH}$ using all 21 polymorphic markers. Among the 108 DNAs analyzed, 52\% (56 cases) showed LOH at one or more loci. Of these, 27 cases were uninformative in defining the deletion as they either showed LOH at all informative loci or exhibited microsatellite instability. The remaining 29 cases had deletions at one or more loci that were within the consensus region of loss, while retaining heterozygosity at the flanking loci. These 29 tumors with partial deletions were used in further defining the minimal region of deletion. The pattern of $\mathrm{LOH}$ among them identified a consensus region of deletion with boundaries defined by retention of heterozygosity in at least two tumors and $\mathrm{LOH}$ at interstitial markers (Fig. 2 and online Fig. 3). The revised minimal deletion included four polymorphic markers D12S377, GCT8BO7, 


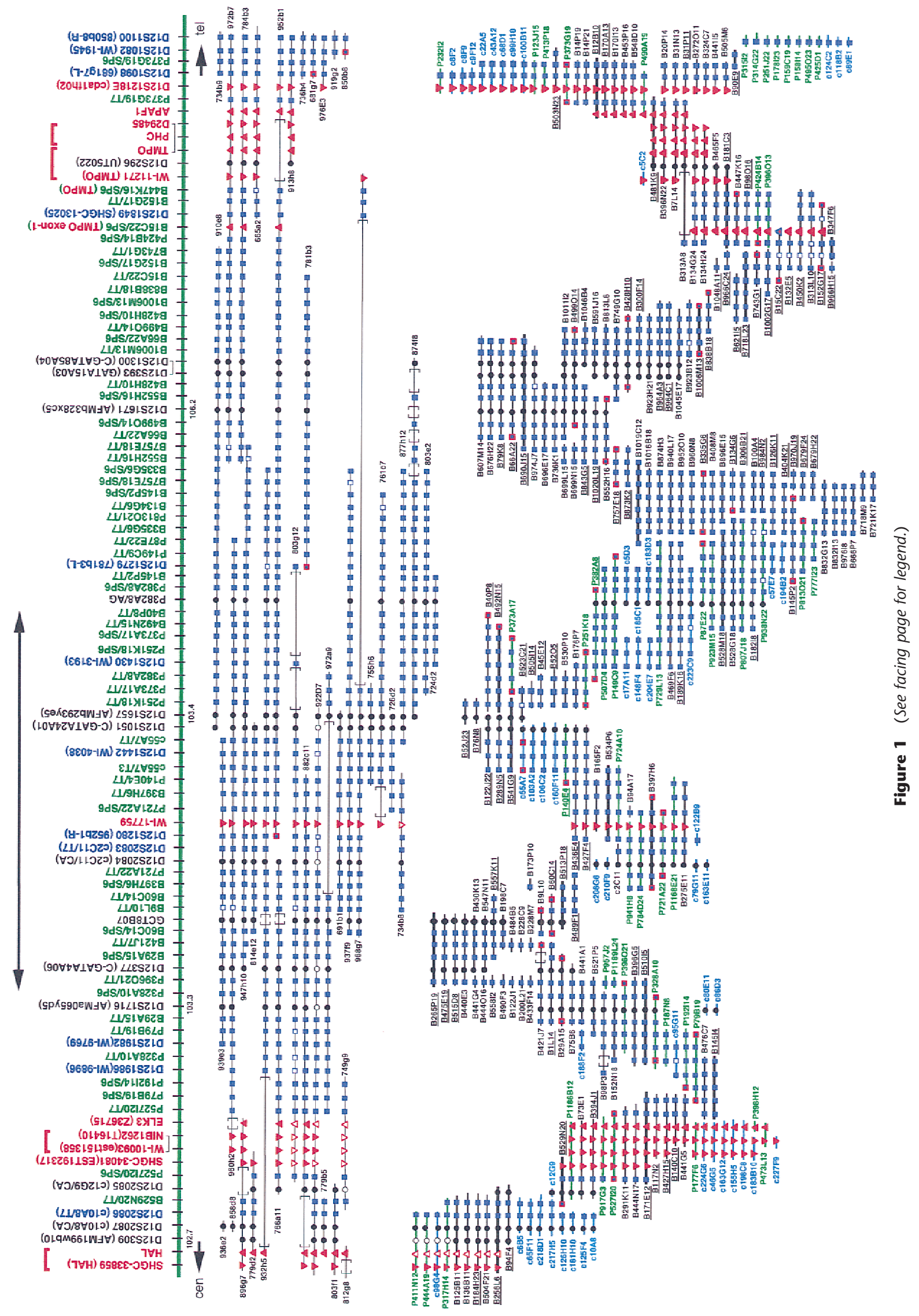

664 Genome Research

www.genome.org 
D12S1051, and D12S1657 flanked by the marker D12S1716 proximally (T-362A, T-167A, T-344A) and P382A8-AG distally (T-225A, T-225B, T-167A, T-320A) (Fig. 2 and online Fig. 3).

\section{Comprehensive Physical Map and Estimation of Sizes of the Contig and the Minimal Deletion}

The combination of mapping of STSs, ESTs, and genebased markers resulted in the construction of a complete BAC, PAC, and cosmid clone contig covering a genetic distance of $4 \mathrm{cM}$ (Fig. 1). This integrated contig map comprised of 42 YACs, 168 BACs, 49 PACs, and 52 cosmids. A total of 99 STS markers have been ordered in the contig, which included 14 polymorphic STSs, 72 nonpolymorphic STSs, 8 ESTs, and 5 genes. To validate the contig generated by STS-content mapping, we performed HindIII restriction fragment fingerprint analysis of 85 BAC and 2 PAC clones, which provided at least double coverage between markers SHGC-33859 and D12S1082 (Fig. 1). Analysis of the fingerprints allowed us to verify the integrity of this set of clones in the minimal tiling path. FISH analysis of 13 BACs and 1 PAC confirmed the position of these clones to $12 \mathrm{q} 22$ (data not shown). The size of the BAC/PAC-contig between SHGC-33859 and D12S1082 was estimated from the clones contained within the minimal tiling path. The estimate is based on an average insert size of 177 $\mathrm{kb}$ for the BAC clones in this library (http://bacpac. med.buffalo.edu/). The minimal tiling path consists of 22 BAC clones. Based on this, the total size of these clones is estimated to be $3894 \mathrm{~kb}(177 \times 22)$. The minimal tiling path comprised 132 markers with 34 overlapping, suggesting a $25 \%$ overlap. Thus, the size of the contig at $75 \%$ is estimated to be $2920 \mathrm{~kb}$. Therefore, the average marker resolution in the contig is 30 $\mathrm{kb}$. In a similar evaluation, the minimal deleted region between the markers D12S1716 and P382A8-AG was estimated as $830 \mathrm{~kb}$.

\section{DISCUSSION}

We previously identified a candidate TSG site at 12q22 in male GCTs characterized by frequent cytogenetic deletion (Murty et al. 1990; Samaniego et al. 1990; Rodriguez et al. 1992) and LOH (Murty et al. 1992, 1996). The LOH analysis also identified a 3-cM common minimal region of deletion between the markers D12S377 and D12S296, which was estimated to be 1.7 $\mathrm{Mb}$, based on the YAC contig of the deleted region (Murty et al. 1996). In the present study, in a continuing effort to isolate the candidate gene, we assembled an STS-content based cosmid, PAC, and BAC contig. These smaller genomic clones serve as better reagents for isolation of new STSs and ESTs and to generate a complete sequence of the region. The STSs placed on the previous YAC contig were used to screen genomic libraries to identify corresponding cosmid, PAC, and BAC clones by bidirectional chromosome walking.

The high-resolution physical map of the 12q22 region generated in this study spans $\sim 3 \mathrm{Mb}$ with complete coverage of the minimal region of deletion in male GCTs. This map represents a better resource for identification of the candidate TSG in several ways. The clones in the map provide substrates for generation of new polymorphic markers by screening for repeat sequences. In fact, we have identified one such informative marker that mapped in the minimal deleted region, which allowed us to narrow the previously identified $1.7-\mathrm{Mb}$ minimal deletion to $830 \mathrm{~kb}$. Availability of additional highly polymorphic markers may allow further reduction in size of the minimal deletion and simplify positional cloning efforts. The contig permits an accurate placement of new genes and ESTs on the map by PCR. To date, we have mapped 13 ESTs including five genes (HAL, ELK3, TMPO, PHC, and $A P A F 1)$, all outside the minimal deleted region. The TMPO (Harris et al. 1995), PHC (Marsh et al. 1995), and APAF1 (Zou et al. 1997) genes have been mapped outside at the distal border, whereas HAL (Suchi et al. 1995) and ELK3 (Giovane et al. 1994, 1995) lie proximal to the minimal deletion. We have previously excluded TMPO as a target candidate TSG (Murty et al. 1996). The genomic structure of APAF1 has been characterized and its role in GCTs is under investigation (S. Bala, H. Oliver, B. Renault, K. Montgomery, S. Dutta, P.

Figure 1 Integrated physical map of the 12q22 deleted region in male GCTs. The map between the interval SHGC-33859 (proximal) and D12S1100 (distal) is composed of 42 previously mapped YACs and 168 BACs, 49 PACs, and 52 cosmids isolated in this study. The solid green bar (top) represents the chromosomal region in proximal to distal orientation. The markers ordered on the contig are shown above the green bar (distances in the map are not to scale). All markers shown in green and P382A8/AG (shown in black) were generated in this study by sequencing ends of the clones. Markers are color-coded as follows: (blue and green) nonpolymorphic; (red) EST/gene; (black) polymorphic. Red brackets above the markers indicate that the ESTs are in the same unigene cluster. Small black brackets above the green line indicate that the relative order of the markers could not be determined unambiguously. The numbers below the green line indicate the genetic map position on chromosome 12 (Généthon map). The first level of the map below the green line represents YACs (black lines); the second level (below the YAC contig) represents BAC, PAC, and cosmid clone contig. The prefix B denotes BACs (black), P denotes PACs (green), and c denotes cosmids (blue). The STS content of each clone is indicated by symbols: (black circle) polymorphic marker; (blue square) nonpolymorphic marker; (blue square with red border) clone-end marker generated by sequencing; (downward red triangle) EST; (upward red triangle) gene; (upward red triangle with blue border) gene sequence identified from an end sequence. Open symbols indicate that the marker was not tested. A bracket within YAC or BAC clone indicates lack of marker(s), which may represent internal deletion. The large bidirectional arrow (top) indicates the minimal region of deletion. BAC clones drawn in thick, black lines represent minimal tiling path. Underlined clones indicate fingerprinted clones. 
Murty et al.

Table 1. STSs and ESTs Mapped in the Present Study

\begin{tabular}{|c|c|c|c|}
\hline Locus & Clone/gene & Primer sequence $\left(5^{\prime}-3^{\prime}\right)$ & $\begin{array}{c}\text { Source } \\
\text { (GenBank acc. no.) }\end{array}$ \\
\hline \multicolumn{4}{|l|}{ Polymorphic STSs } \\
\hline D12S309 & AFM199wb10 & - & Weissenbach et al. (1992) \\
\hline D12S2087 & C10A8/CA & - & $\begin{array}{l}\text { LeBlanc-Straceski et al. } \\
\text { (1994) }\end{array}$ \\
\hline DIZSZUO & CIOHO/CA & - & LeBlanc-Straceski et al. \\
\hline D12S2085 & C12G9/CA & - & (1994) \\
\hline$D 1251716$ & AFMa065yd5 & - & GDB \\
\hline D12S377 & GATA4AO6 & - & GDB \\
\hline - & GCT8BO7 & - & $\mathrm{CHLC}$ \\
\hline & & & LeBlanc-Straceski et al. \\
\hline D12S2084 & $\mathrm{C} 2 \mathrm{C} 11 / \mathrm{CA}$ & - & (1994) \\
\hline D12S1051 & GATA24A01 & - & GDB \\
\hline$D 12 S 1657$ & AFMb293ye5 & - & GDB \\
\hline- & P382A8/AG & $\begin{array}{l}\text { (F)AAGACCCCAGACCCAATGTA } \\
\text { (R) TCTGTCACCAACACTCACTGC }\end{array}$ & this study (AQ254947) \\
\hline$D 1251671$ & AFMb328xc5 & - & GDB \\
\hline D12S393 & GATA15AO3 & - & GDB \\
\hline$D 12 S 1300$ & GATA85A04 & - & GDB \\
\hline$D 12 S 296$ & UT5022 & - & GDB \\
\hline \multicolumn{4}{|l|}{ Nonpolymorphic STSs } \\
\hline D12S2086 & c10A8/T7 & - & $\begin{array}{l}\text { LeBlanc-Straceski et al. } \\
\text { (1994) }\end{array}$ \\
\hline- & B529N20/T7 & $\begin{array}{l}\text { (F) CCAAGGAACCCACAGAGTTT } \\
\text { (R) GAAGCATCTCAATTCCCCA }\end{array}$ & this study (AQ254896) \\
\hline - & P527I20/SP6 & $\begin{array}{l}\text { (F) GTTGCACCATCCTTCCTGAC } \\
\text { (R) CACCACCCAGTGGAAACATT }\end{array}$ & this study (AQ254931) \\
\hline- & P527I20/T7 & $\begin{array}{l}\text { (F) CTGGAGTCCGAAATGTTGGT } \\
\text { (R) AACTCCACTGGAAGAAGGCA }\end{array}$ & this study (AQ254932) \\
\hline- & P79B19/SP6 & $\begin{array}{l}\text { (F) CGCAATTTTCCTCCCATAAA } \\
\text { (R) CCTGAATCCTGGCATCTTCT }\end{array}$ & this study (AQ254933) \\
\hline- & P192I14/SP6 & $\begin{array}{l}\text { (F) AAGGGATATTTTCAGTCCTCCC } \\
\text { (R) TCACACAGCAATGTGAATGC }\end{array}$ & this study (AQ254934) \\
\hline D12S1986 & WI-9896 & - & WI-MIT/RH \\
\hline- & P328A10/T7 & $\begin{array}{l}\text { (F) ATACTCACAGCGCACGCTCT } \\
\text { (R) ATGAGCTTTCCCTTGCTTTG }\end{array}$ & this study (AQ254935) \\
\hline D12S1982 & WI-9769 & - & \\
\hline - & Р79B19/T7 & $\begin{array}{l}\text { (F) TGAAGTTCCACCACTCATATCC } \\
\text { (R) CTTGGTTTGCTGAGACCACA }\end{array}$ & this study (AQ254936) \\
\hline - & B29A15/T7 & $\begin{array}{l}\text { (F) ATTTGGGACCTTATCCAGGG } \\
\text { (R) GCCCTTCACCAATGACAGAT }\end{array}$ & this study (AQ254897) \\
\hline - & P328A10/SP6 & $\begin{array}{l}\text { (F) GTGACACCTGACGGGGTAGT } \\
\text { (R) AGGAAGGAGTAGCAGGCACA }\end{array}$ & this study (AQ254937) \\
\hline - & P396021/T7 & $\begin{array}{l}\text { (F) TGCGATGGGTTTTAACTTCC } \\
\text { (R) ACCAAAACCCCATCTGTACG }\end{array}$ & this study (AQ254938) \\
\hline- & B29A15/SP6 & $\begin{array}{l}\text { (F) CGACTGATTCGCTATGGACA } \\
\text { (R) AGCACATCTGCCTGAAACCT }\end{array}$ & this study (AQ254898) \\
\hline - & $\mathrm{B} 421 \mathrm{~J} / \mathrm{TT} 7$ & $\begin{array}{l}\text { (F) AGAGAACAAGGTGCTTCCCA } \\
\text { (R) GAGAGACTGGCTTCCTGGTG }\end{array}$ & this study (AQ254899) \\
\hline - & B60C $14 / S P 6$ & $\begin{array}{l}\text { (F) TGCAGAAATGGCACCTAACA } \\
\text { (R) TTGAATCCCGGAGAAGGTAA }\end{array}$ & this study (AQ254900) \\
\hline- & B9L10/T7 & $\begin{array}{l}\text { (F) GCAGCCTCTCAGGATACCAG } \\
\text { (R) GGCAGCTCCTCATTTCTCAG }\end{array}$ & this study (AQ254901) \\
\hline- & $\mathrm{B} 60 \mathrm{C} 14 / \mathrm{T} 7$ & $\begin{array}{l}\text { (F) GGAATTCTGCCTCCAGATTG } \\
\text { (R) CACACAGAGAGGCTGAGAG }\end{array}$ & this study (AQ254902) \\
\hline - & B397H6/SP6 & $\begin{array}{l}\text { (F) TCGCATCTTAGGCTCACAAA } \\
\text { (R) TCAGGATCTCCATGCTCAAG }\end{array}$ & this study (AQ254903) \\
\hline - & $\mathrm{P} 721 \mathrm{~A} 22 / \mathrm{T} 7$ & $\begin{array}{l}\text { (F) TGCCAGCATCACAAGACTTC } \\
\text { (R) GTGGAGAAGAAACCGAGCTG }\end{array}$ & this study (AQ254939) \\
\hline D12S2083 & $\mathrm{c} 2 \mathrm{C} 11 / \mathrm{T} 7$ & (1) & $\begin{array}{l}\text { LeBlanc-Straceski et al. } \\
\text { (1994) }\end{array}$ \\
\hline D12S1280 & $952 \mathrm{~b} 1-\mathrm{R}$ & - & $\mathrm{AECOM} / \mathrm{GDB}$ \\
\hline- & P721A22/SP6 & $\begin{array}{l}\text { (F) TCACCTCCTAGGCTCCACAC } \\
\text { (R) CAATTTGGGTGGCTTTCTGT }\end{array}$ & this study (AQ254940) \\
\hline
\end{tabular}


Table 1. (Continued)

\begin{tabular}{|c|c|c|c|}
\hline Locus & Clone/gene & Primer sequence $\left(5^{\prime}-3^{\prime}\right)$ & $\begin{array}{c}\text { Source } \\
\text { (GenBank acc. no.) }\end{array}$ \\
\hline$\overline{-}$ & B397H6/T7 & $\begin{array}{l}\text { (F) GCTTTGGTTTTTGTGCATGA } \\
\text { (R) GAAAGGCCATTTCAAGGGTT }\end{array}$ & this study (AQ254904) \\
\hline- & P140E4/T7 & $\begin{array}{l}\text { (F) AGAGTCTGAGGAACGGAAA } \\
\text { (R) ATCTCGAGAAATCCTTGAGGTG }\end{array}$ & this study (AQ254941) \\
\hline- & $\mathrm{c} 55 \mathrm{~A} 7 / \mathrm{T} 3$ & $\begin{array}{l}\text { (F) ACAGGGATGTGGCAAGATGT } \\
\text { (R) AAGGAGGAAGAAAACACGGG }\end{array}$ & this study (AQ254954) \\
\hline D12S1442 & WI-4038 & - & GDB \\
\hline- & c55A7/T7 & $\begin{array}{l}\text { (F) TTGGCCATTACGTGGAAAAT } \\
\text { (R) TCTGCATCAAAACCTTTCCC }\end{array}$ & this study (AQ254955) \\
\hline- & P251K18/T7 & $\begin{array}{l}\text { (F) AАTCCATTGCTTCTGGGACTG } \\
\text { (R) CTGACСTTTCAAGAATGCATCTG }\end{array}$ & this study (AQ254942) \\
\hline - & P373A17/T7 & $\begin{array}{l}\text { (F) TCTCTGCCTTTGCAAATCCT } \\
\text { (R) TTTGGACAACAAGAGACAAACG }\end{array}$ & this study (AQ254943) \\
\hline- & P382A8/T7 & $\begin{array}{l}\text { (F) AACAGGCACAGGAAATCCAA } \\
\text { (R) AATGGTGCACCTTCCCAATA }\end{array}$ & this study (AQ254944) \\
\hline $\begin{array}{l}\text { D12S1430 } \\
-\end{array}$ & $\begin{array}{l}\text { WI-3193 } \\
\text { P251K18/SP6 }\end{array}$ & $\begin{array}{l}\text { (F) TTACCTGTATTTTCTGCACCCA } \\
\text { (R) CAATACTATGGGCAGAGCCTT }\end{array}$ & $\begin{array}{l}\text { GDB } \\
\text { this study (AQ254945) }\end{array}$ \\
\hline- & P373A17/SP6 & $\begin{array}{l}\text { (F) CCCAACTCTTTGAGGCCATA } \\
\text { (R) TTTCAATCCGTTCCGTTTTC }\end{array}$ & this study (AQ254946) \\
\hline - & B492N15/T7 & $\begin{array}{l}\text { (F) CCCTGCCTCCTATGCTACTT } \\
\text { (R) GCTGCATGGCATTCTACAGT }\end{array}$ & this study (AQ254905) \\
\hline- & B40P8/T7 & $\begin{array}{l}\text { (F) ACGCATTTCCAGGAGACATC } \\
\text { (R) CTGGGGCAGAGAATATCCAA }\end{array}$ & this study (AQ254906) \\
\hline- & P382A8/SP6 & $\begin{array}{l}\text { (F) TGCAGTGAGTGTTGGTGACA } \\
\text { (R) GAGATATTGATGCCCTGGGA }\end{array}$ & this study (AQ254947) \\
\hline- & B145P2/T7 & $\begin{array}{l}\text { (F) TTCAAGTGTGCTTCCTGCAC } \\
\text { (R) TGGCCCCTTCTTAGTTGATG }\end{array}$ & this study (AQ254907) \\
\hline D12S1279 & 781b3-L & - & $\mathrm{AECOM} / \mathrm{GDB}$ \\
\hline- & P149C9/T7 & $\begin{array}{l}\text { (F) CAGGGCTCCTGAATGTTTGT } \\
\text { (R) AATCATACCTCTCCCTGGGC }\end{array}$ & this study (AQ254948) \\
\hline - & P87E22/T7 & $\begin{array}{l}\text { (F) CСССТTACССССАATTAAAA } \\
\text { (R) AGTGTTGTGGCAAAGGGAAC }\end{array}$ & this study (AQ254949) \\
\hline - & B335G6/T7 & $\begin{array}{l}\text { (F) GCAAATGCCAACACAGCTTA } \\
\text { (R) GAAGACCTATGCCCCAGGAT }\end{array}$ & this study (AQ254908) \\
\hline - & P813021/T7 & $\begin{array}{l}\text { (F) GAGGCCATTACCCTTAGCAA } \\
\text { (R) TTCATCCCCAAATACCAAGC }\end{array}$ & this study (AQ254950) \\
\hline- & B134G6/T7 & $\begin{array}{l}\text { (F) ATGTTCCTTGCTGGAAGCTC } \\
\text { (R) TCTTGGTTTCCATGAGGAGG }\end{array}$ & this study (AQ254909) \\
\hline - & B145P2/SP6 & $\begin{array}{l}\text { (F) AACCTCTGAAGCAGACCAACA } \\
\text { (R) TCTCATCAAGGAAAAATTCCAAA }\end{array}$ & this study (AQ254910) \\
\hline - & B757E18/SP6 & $\begin{array}{l}\text { (F) TAGACCGACATAAGCAGGGC } \\
\text { (R) ATCAGAAGCTGTTCATCGCC }\end{array}$ & this study (AQ254911) \\
\hline - & B335G6/SP6 & $\begin{array}{l}\text { (F) TGACCTTCCATTTCCCTGAG } \\
\text { (R) AAAGGAAAGGTTGGCAAGGT }\end{array}$ & this study (AQ254912) \\
\hline - & B552H16/T7 & $\begin{array}{l}\text { (F) GGCTTGGCACTTTGTCTTTT } \\
\text { (R) GCATTGAAGGAAGGGATGTC }\end{array}$ & this study (AQ254913) \\
\hline - & B757E18/T7 & $\begin{array}{l}\text { (F) AAGGGGAAGGCATCCTTAGA } \\
\text { (R) CAGACAGCTGCTTACCTCCC }\end{array}$ & this study (AQ254914) \\
\hline- & $\mathrm{B} 66 \mathrm{~A} 22 / \mathrm{T} 7$ & $\begin{array}{l}\text { (F) GCTGCATCACTCTGTTTCCA } \\
\text { (R) CAGGTAAAAATGGGAAGGCA }\end{array}$ & this study (AQ254915) \\
\hline - & B499014/SP6 & $\begin{array}{l}\text { (F) CCCCAGCAAATGTTCCTCTA } \\
\text { (R) AAGGCATTGGGTTAGTGCTG }\end{array}$ & this study (AQ 254916) \\
\hline - & B552H16/SP6 & $\begin{array}{l}\text { (F) CTCCAACATGGTCCAGATCC } \\
\text { (R) ACCCTTCCAAGGTAAGGCTC }\end{array}$ & this study (AQ254917) \\
\hline - & $\mathrm{B} 428 \mathrm{H} 10 / \mathrm{T} 7$ & $\begin{array}{l}\text { (F) GGAGCTCAAGCATCTTACGG } \\
\text { (R) GGGATTAGCCATTGAGGGAT }\end{array}$ & this study (AQ254918) \\
\hline - & B1006M13/T7 & $\begin{array}{l}\text { (F) TAACAGCCCCTTGGAACATC } \\
\text { (R) GGTGAGTTGGTTGAATGGCT }\end{array}$ & this study (AQ254919) \\
\hline - & B66A22/SP6 & $\begin{array}{l}\text { (F) TTGGGGGTGCTATCTTATGC } \\
\text { (R) GGAGAGGGATGAGTTGGTGA }\end{array}$ & this study (AQ254920) \\
\hline - & B499014/T7 & $\begin{array}{l}\text { (F) TCAAGGAGAGAATGTTGCCA } \\
\text { (R) CAGTGGCACTAGGGAAGATGA }\end{array}$ & this study (AQ254921) \\
\hline - & $\mathrm{B} 428 \mathrm{H} 10 / \mathrm{SP} 6$ & $\begin{array}{l}\text { (F) GAAACAGCGACAGCATGAAA } \\
\text { (R) TCTGATCTGTGGAAGCATCG }\end{array}$ & this study (AQ254922) \\
\hline
\end{tabular}


Table 1. (Continued)

\begin{tabular}{|c|c|c|c|}
\hline Locus & Clone/gene & Primer sequence $\left(5^{\prime}-3^{\prime}\right)$ & $\begin{array}{c}\text { Source } \\
\text { (GenBank acc. no.) }\end{array}$ \\
\hline- & B1006M13/SP6 & $\begin{array}{l}\text { (F) AAGGGGATTCAGTGGTCAAA } \\
\text { (R) CTGGTAGTCCCATAGGATTTAATTG }\end{array}$ & this study (AQ254923) \\
\hline- & B838B18/T7 & $\begin{array}{l}\text { (F) TGCCTTCCTCTCTACCAGGA } \\
\text { (R) CTCTAGGGGCAACAACTTGG }\end{array}$ & this study (AQ254924) \\
\hline- & B15C22/T7 & $\begin{array}{l}\text { (F) CTGATGAGGGGCTAAAGCTG } \\
\text { (R) AGGGTTAAATCCAGGTTGGG }\end{array}$ & this study (AQ254925) \\
\hline- & B152G17/SP6 & $\begin{array}{l}\text { (F) CAGCATGAACTCTTCCTGACC } \\
\text { (R) CATGGTACAAAATGGTCCCG }\end{array}$ & this study (AQ254926) \\
\hline- & B743G1/T7 & $\begin{array}{l}\text { (F) CAGCCAATCAGTGATGCAGT } \\
\text { (R) CTGCCTGTGGAGTACCCATT }\end{array}$ & this study (AQ254927) \\
\hline- & P424B14/SP6 & $\begin{array}{l}\text { (F) TGCCATTTATTCCCGAAGAG } \\
\text { (R) CTGCTCCTTTTTCATCCCTG }\end{array}$ & this study (AQ254951) \\
\hline- & B15C22/SP6 & $\begin{array}{l}\text { (F) TTITGTTCCAGAAACCCAGG } \\
\text { (R) AAAGCCAGAGACGGTTTCAA }\end{array}$ & this study (AQ254928) \\
\hline D12S1849 & SHGC-13025 & - & GDB \\
\hline- & B152G17/T7 & $\begin{array}{l}\text { (F) AGCCTGACAAATGCCTCAGT } \\
\text { (R) AGCCTGACAATTCTAGGGTCA }\end{array}$ & this study (AQ254929) \\
\hline- & B447K16/SP6 & $\begin{array}{l}\text { (F) CAGGCAAACTACCTACCCCA } \\
\text { (R) AGATCAATCGCCTCTCTCCA }\end{array}$ & this study (AQ254930) \\
\hline- & P373G19/T7 & $\begin{array}{l}\text { (F) TCCCTCTGCTGTTAGCTTCC } \\
\text { (R) TCTTCAGTTTCCATGTCCCA }\end{array}$ & this study (AQ254952) \\
\hline D12S1098 & $681 \mathrm{~g} 7-\mathrm{L}$ & - & GDB \\
\hline- & P373G19/SP6 & $\begin{array}{l}\text { (F) CCTCTGGTGATTGCAAGGAT } \\
\text { (R) GTCGTGTATCAAAAACCGGG }\end{array}$ & this study (AQ254953) \\
\hline D12S1082 & WI-1945 & - & GDB \\
\hline $\begin{array}{l}\text { D12S1100 } \\
\text { ESTs }\end{array}$ & 850b8-R & - & AECOM/GDB \\
\hline$\overline{S G C} 33859$ & $H A L$ & - & GDB \\
\hline SGC34081 & EST192317 & - & GDB \\
\hline WI-10093 & EST151358 & - & GDB \\
\hline NIB1262 & T16410 & - & GDB \\
\hline WI-17759 & - & - & GDB \\
\hline WI-11271 & TMPO & - & GDB \\
\hline D29485 & EST77185 & - & GDB \\
\hline $\begin{array}{l}\text { D12S1218E } \\
\text { Genes }\end{array}$ & cda1fhO2 & - & GDB \\
\hline$\overline{H A L}$ & - & - & AECOM/GDB \\
\hline ELK3 & Z36715 & $\begin{array}{l}\text { (F) ACGTCTGGCCACAATTAAGG } \\
\text { (R) TGTCCTTCTCACGACACAGG }\end{array}$ & this study \\
\hline TMPO & - & - & Harris et al. (1995) \\
\hline PHC & - & - & Marsh et al. (1995) \\
\hline APAF1 & - & - & Zou et al. (1997) \\
\hline
\end{tabular}

(AECOM) Albert Einstein College of Medicine; (APAF1) apoptosis protease activating factor 1; (ELK3) ETS-domain protein; (GDB) human Genome Database; (CHLC) The Cooperative Human Linkage Center; (WI-MIT/RH) Whitehead Institute Radiation Hybrid map; (NCBI) National Center for Biotechnology Information; (HAL) histidine ammonia-lyase; (PHC) phosphate carrier, mitochondrial; (TMPO) human thymopoietin.

Rao, J. Houldsworth, G. Bosl, R. Kucherlapati, X. Wang, et al., in prep.). EST WI-17759 maps within the minimal deleted region and its analysis in relation to GCTs is in progress. The clones in the region provide excellent resource for sequencing, exon trapping, and cDNA selection. A set of BAC clones in the minimal tiling path is being sequenced at the Genome Sequencing Center at Baylor College of Medicine (see http:// sequence.aecom.yu.edu/chr12/).

The present map represents the most comprehensive and accurate map of the 12q22 region currently available. It contains 99 markers with an average marker resolution of $30 \mathrm{~kb}$ whereas the Whitehead In- stitute's Radiation Hybrid map (WI-RH) and Stanford RH map (Stewart et al. 1997) contains only 13 and 11 markers, respectively, within this interval. Only 4 markers are shared between WI-RH and Stanford RH maps. Of the 13 markers in the WI-RH map, 11 are identified in our map whereas our map shares only six markers with the Stanford RH map. The order of markers is the same in our map and the Stanford map, except that we could not resolve the order of D12S393 and D12S1300. The WI-RH map and our map have two discrepancies. Our map placed SHGC-34081 proximal to WI-10093, whereas the order in the WI-RH map is reversed, and we mapped WI-11271 distal to 
D12S1300/D12S393, whereas the WI-RH map placed it proximal to these markers. The order of the markers in our map is likely to be accurate as it is based on STS content mapping.

LOH analysis of GCTs performed in the present study enabled us to further refine the region of common deletion at $12 \mathrm{q} 22$ by the use of the additional polymorphic markers P383A8-AG and D12S1671. Based on $\mathrm{LOH}$ analysis utilizing these two markers, four tumors (T-225A, T-225B, T-167A, and T-320A) retained heterozygosity at markers D12S1671 and P382A8-AG in the distal half of the previously described region of minimal deletion. Thus, the refined minimal deletion spans four polymorphic markers (D12S377, GCT8B07, D12S1051, and D12S1657) compared to nine markers that spanned the previously defined minimal deletion, reducing it to approximately half the size (Murty et al. 1996). The region of chromosome 12q22 also demonstrated high frequency of $\mathrm{LOH}$ in a variety of other tumors such as pancreatic (Seymour et al. 1994; Hahn et al. 1995; Kimura et al. 1996, 1998) and gastrointestinal (Fey et al. 1989; Schneider et al. 1995) carcinomas. Our physical map provides valuable reagents for the positional cloning of candidate genes involved in these tumors if different from the one in GCT.

Taken together, the availability of high-resolution cosmid, PAC, and BAC map and the refined interval of minimal deletion containing the candidate TSG provides a basis for isolation of the gene at $12 \mathrm{q} 22$ region in GCTs. The map will further allow the identification of other novel genes present within this interval.

Table 2. LOH at $12 q 22-q 24$ in GCTs Assayed by Polymorphic STSs

\begin{tabular}{lcccc}
\hline Locus & $\begin{array}{c}\text { No. } \\
\text { studied }\end{array}$ & $\begin{array}{c}\text { No. } \\
\text { informative }\end{array}$ & $\begin{array}{c}\text { No. with } \\
\text { LOH }\end{array}$ & $\begin{array}{c}\text { Percent } \\
\text { LOH }\end{array}$ \\
\hline D12S81 & 108 & 67 & 19 & 28 \\
D12S379 & 108 & 79 & 27 & 34 \\
D12S101 & 106 & 57 & 19 & 33 \\
D12S309 & 108 & 79 & 24 & 30 \\
D12S2087 & 106 & 57 & 22 & 39 \\
D12S2085 & 108 & 70 & 31 & 44 \\
D12S1716 & 107 & 59 & 29 & 49 \\
D12S377 & 107 & 72 & 28 & 39 \\
GC18B07 & 102 & 29 & 10 & 34 \\
D12S1051 & 107 & 86 & 38 & 44 \\
D12S1657 & 108 & 58 & 26 & 45 \\
P382A8-AG & 98 & 79 & 25 & 32 \\
D12S1671 & 105 & 71 & 21 & 30 \\
D12S1300 & 106 & 68 & 31 & 46 \\
D12S393 & 108 & 69 & 30 & 43 \\
D12S296 & 104 & 63 & 25 & 40 \\
D12S346 & 105 & 82 & 26 & 32 \\
D12S58 & 107 & 63 & 20 & 32 \\
D12S234 & 98 & 69 & 16 & 23 \\
D12S367 & 107 & 82 & 19 & 23 \\
D12S392 & 107 & 75 & 21 & 28 \\
& & & &
\end{tabular}

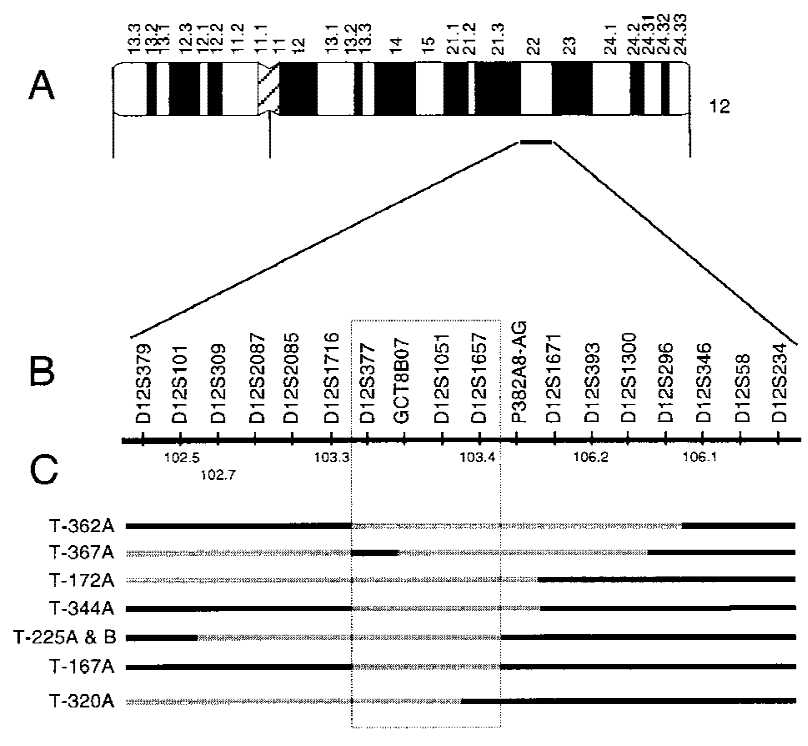

Figure 2 Identification of minimal deleted region at $12 q 22$ by $\mathrm{LOH}$ analysis in male GCTs. (A) G-banded ideogram of chromosome 12 and the corresponding 12q22 deleted region identified by previous studies (Murty et al. 1992, 1996). (B) Physical map order depicting polymorphic markers used in $\mathrm{LOH}$ analysis from centromeric (left) to telomeric (right) orientation. The numbers below indicate the genetic distances on chromosome 12 (Généthon map; Dib et al. 1996). (C) Pattern of LOH in eight tumors that define the minimal deleted region. Tumor numbers are shown at left. Solid lines indicate region of retention of heterozygosity; shaded lines indicate region of $\mathrm{LOH}$. The boxed region indicates the consensus minimal region of deletion (for definition, see Methods).

\section{METHODS}

\section{Identification of Cosmid, PAC, and BAC Clones}

We previously identified 53 overlapping YACs in a contiguous map of the12q22 region covering a 4-cM genetic distance (Murty et al. 1996). This YAC contig served as a framework map to generate a smaller genomic clone contig comprised of cosmids, PACs, and BACs. In the present study, two human chromosome 12 cosmid libraries (LL12NCO1 and LL12NCO2) (Montgomery et al. 1993), human genomic PAC (RPCI-1, RPCI-3, RPCI-4, RPCI-5) (Ioannou et al. 1994), and BAC (RPCI-11) libraries obtained from Roswell Park Cancer Institute (provided by Pieter de Jong) were used. High-density gridded filters were hybridized with pooled PCR probes generated from nonpolymorphic markers and ESTs (Table 1). The probes were generated by PCR of YAC DNA known to contain the markers. They were gel-purified and $100 \mathrm{ng}$ of each probe were labeled with $\left[\alpha-{ }^{32} \mathrm{P}\right] \mathrm{dCTP}$ by random priming. The probes were pooled together and hybridized to the highdensity filters after suppression with Cot 1 DNA at $65^{\circ} \mathrm{C}$ following standard methods. Positive clones were identified on autoradiograms and picked from library plates. All clones were grown in Luria broth or $2 \times$ YT medium in $5 \mathrm{ml}$ of culture, and DNA was isolated by an alkaline lysis procedure. YAC clones were grown in acid-hydrolyzed casein (AHC) medium for two days at $30^{\circ} \mathrm{C}$ and DNA was prepared by the standard mini-preparation method (Krauter et al. 1995). The DNAs were tested by PCR for the presence of individual STS/ ESTs used for hybridization, initially on pools, and then on 
members of positive pools testing with individual markers. Such analysis permitted conversion of the YAC contig map to a cosmid, PAC, and BAC map. End sequences of the clones were obtained using T3, T7, or SP6 vector-end sequencing primers and dye-terminator sequencing. The sequences generated from clone ends were used to search the public databases to identify homology with existing sequences and to identify unique sequences. New nonpolymorphic STSs were designed from the unique sequences using Primer 3 program from the Whitehead Institute's web site (http://wwwgenome.wi.mit.edu/). These STSs were used for the next round of screening of cosmid, PAC, and BAC filters. Several rounds of library screening were performed to complete the map.

\section{Isolation of New STSs and Construction of Cosmid/PAC/BAC Clone Contig}

All newly identified cosmid, PAC, and BAC clones were first confirmed by PCR for their position in the YAC framework map by using the original primers for the STS/EST marker. Once the map position of a new clone was confirmed, the ends were sequenced, primers were designed, and STSs were generated as described above (Table 1). Optimal PCR amplification conditions were tested for each set of new STS and EST primers. The STSs that amplified poorly or resulted in nonspecific PCR products, as well as the clones whose positions could not be readily established, were excluded from the map. The STS-content mapping was performed on appropriately diluted (10- to 100-fold) clone DNAs by PCR in a final volume of $10 \mu \mathrm{l}$ using AmpliTaq DNA polymerase (Perkin-Elmer, Foster City, CA) by standard methods and the products were run on $2 \%$ agarose gels stained with ethidium bromide. ESTs mapped in the interval of the YAC contig were identified from the public databases (Schuler et al. 1996; Genome Maps 7, National Center for Biotechnology Information; Integrated Map of Whitehead Institute; RH consortium map of Genome Data Base) (Table 1) and obtained from Research Genetics (Huntsville, AL). All positive clones were also tested for adjacent loci by STS content analysis. Overall, all clones were tested for STS content of all markers in the contig either as pools or as individual clones, and the resulting data were analyzed manually. In order to confirm the integrity of the clones in the contig, a DNA fingerprint was generated. A redundant set of clones was selected and grown in $5 \mathrm{ml}$ culture, DNA was prepared as above, and 100-500 ng of DNA was digested with HindIII and electrophoresed on 1.0\% agarose gel in TAE buffer for $22 \mathrm{hr}$ at $70 \mathrm{~V}$ as described (Marra et al. 1997; Renault et al. 1997). The gel was stained with SYBR Green (FMC Bioproducts, ME) and the image was scanned by the Molecular Dynamics FT595 fluorimager. The images were visually reviewed to ascertain magnitude of overlap between and adjacent clones in the contig and to rule out gross rearrangements.

\section{Tumor and Normal DNA}

Tumor tissues and the corresponding normal cells were obtained, after informed consent, from patients with GCTs evaluated at the Memorial Sloan-Kettering Cancer Center as described (Murty et al. 1996). A total of 108 normal-tumor DNAs derived from 97 patients were utilized for the LOH studies. Of these, eight were analyzed as cell lines and their derivation was reported previously (Murty et al. 1996). All histologic types (seminomatous and nonseminomatous), sites of presentation, as well as primary and metastatic states, were represented in the study.

\section{Analysis of $\mathrm{LOH}$}

A total of 21 microsatellite markers were utilized in the LOH analysis. These include 18 previously used markers (Murty et al. 1996) and 3 additional markers (GCT8B07, D12S1671, and P382A8-AG) including one isolated in the present study (Table 1). PCR amplification, electrophoresis, and analysis of LOH were performed as described previously (Murty et al. 1996). The criterion applied to define consensus minimal deletion was that the markers mapped in that interval exhibit $\mathrm{LOH}$ in all tumors with retention of heterozygosity of proximal and distal makers in at least two different cases.

\section{ACKNOWLEDGMENTS}

This work was supported by the National Institutes of Health grant CA75925 (V.V.V.S.M.) and the Byrne Fund (R.S.K.C.).

The publication costs of this article were defrayed in part by payment of page charges. This article must therefore be hereby marked "advertisement" in accordance with 18 USC section 1734 solely to indicate this fact.

\section{REFERENCES}

Chaganti, R.S.K., V.V.V.S. Murty, and G.J. Bosl. 1996. Molecular genetics of male germ cell tumors. In Comprehensive textbook of genitourinary oncology (ed. N.J. Vogelzang, P.T. Scardino, W.U. Shipley, and D.S. Coffey), pp. 932-940. Williams \& Wilkins, Baltimore, MD.

Dib, C., S. Faure, C. Fizames, D. Samson, N. Drouot, A. Vignal, P. Millasseau, S. Marc, J. Hazan, E. Seboun et al. 1996. A comprehensive genetic map of the human genome based on 5,264 microsatellites. Nature 380: A1-A128.

Fey, M.F., C. Hesketh, J.S. Wainscoat, S. Gendler, and S.L. Thein. 1989. Clonal allele loss in gastrointestinal cancers. Br. J. Cancer 59: $750-754$.

Giovane, A., A. Pintzas, S.M. Maira, P. Sobieszczuk, and B. Wasylyk. 1994. Net, a new ets transcription factor that is activated by Ras. Genes \& Dev. 8: 1502-1513.

Giovane, A., P. Sobieszczuk, C. Mignon, M.G. Mattei, and B. Wasylyk. 1995. Locations of the ets subfamily members net, elk1, and sap1 (ELK3, ELK1, and ELK4) on three homologous regions of the mouse and human genomes. Genomics 29: 769-772.

Hahn, S.A., A.B. Seymour, A.T.M.S. Hoque, M. Schutte, L.T. da Costa, M.S. Redston, C. Caldas, C.L. Weinstein, A. Fisher, C.J. Yeo, R.H. Hruban, and S.E. Kern. 1995. Allelotype of pancreatic adenocarcinoma using xenograft enrichment. Cancer Res. 55: $4670-4675$.

Harris, C.A., P.J. Andryuk, S.W. Cline, S. Mathew, J.J. Siekierka, and G. Goldstein. 1995. Structure and mapping of the human thymopoietin (TMPO) gene and relationship to human TMPO $\beta$ to rat lamin-associated polypeptide 2. Genomics 28: 198-205.

Ioannou, P.A., C.T. Amemiya, J. Garnes, P.M. Kroisel, H. Shizuja, C. Chen, M.A. Batzer, and P.A. de Jong. 1994. A new bacteriophase P1-derived vector for the propagation of large human DNA fragments. Nat. Genet. 6: 84-89.

Kimura, M., T. Abe, M. Sunamura, S. Matsumo, and A. Horii. 1996. Detailed deletion mapping on chromosome arm 12q in human pancreatic adenocarcinoma: Identification of a 1-cM region of common allelic loss. Genes Chromosomes Cancer 17: 88-93.

Kimura, M., T. Furukawa, T. Abe, T. Yatsuoka, E.M. Youssef, T. Tokoyama, H. Ouyang, Y. Ohnishi, M. Sunamura, M. Kobari et al. 1998. Identification of two common regions of allelic loss in chromosome arm 12q in human pancreatic cancer. Cancer Res. 58: $2456-2460$.

Krauter, K., K. Montgomery, S.J. Yoon, J. LeBlanc-Straceski, B. Renault, I. Marondel, V. Herdman, L. Cupelli, A. Banks, J. 
Lieman et al. 1995. A second-generation YAC contig map of human chromosome 12. Nature (Suppl.) 377: 321-333.

Kucherlapati, R., P. Marynen, and C. Turc-Carel. 1997. Report of the Fourth International workshop on human chromosome 12 mapping 1997. Cytogenet. Cell Genet. 78: 81-95.

LeBlanc-Straceski, J.M., K.T. Montgomery, H. Kissel, L. Murtaugh, P. Tsai, D.C. Ward, K.S. Krauter, and R. Kucherlapati 1994. Twenty-one polymorphic markers from human chromosome 12 for integration of genetic and physical maps. Genomics 19: 341-349.

Marra, M.A., T.A. Kucaba, N.L. Dietrich, E.D. Green, B. Brownstein, R.K. Wilson, K.M. McDonald, L.W. Hillier, J.D. McPherson, and R.H. Waterston. 1997. High throughput fingerprint analysis of large-insert clones. Genome Res. 7: 1072-1084.

Marsh, S., N.P. Carter, V. Dolce, V. Iacobazzi, and F. Pelmieri. 1995. Chromosomal localization of the mitochondrial phosphate carrier gene PHC to 12q23. Genomics 29: 814-815.

Murty, V.V.V.S., E. Dmitrovsky, G.J. Bosl, and R.S.K. Chaganti. 1990 Nonrandom chromosome abnormalities in testicular and ovarian germ cell tumor cell lines. Cancer Genet. Cytogenet. 50: 67-73.

Murty, V.V.V.S., J. Houldsworth, S. Baldwin, V. Reuter, W. Hunziker, P. Besmer, G. Bosl, and R.S.K. Chaganti. 1992. Allelic deletion in the long arm of chromosome 12 identify sites of candidate tumor suppressor genes in male germ cell tumors. Proc. Natl. Acad. Sci. 89: 11006-11010.

Murty, V.V.V.S., B. Renault, C.T. Falk, G.J. Bosl, R. Kucherlapati, and R.S.K. Chaganti. 1996. Physical mapping of a commonly deleted region, the site of a candidate tumor suppressor gene, at $12 \mathrm{q} 22$ in human male germ cell tumors. Genomics 35: 562-570.

Montgomery, K.T., J.M. LeBlanc, P. Tsai, J.S. McNinch, D.C. Ward, P.J. DeJong, R. Kucherlapati, and K.S. Krauter. 1993. Characterization of two chromosome 12 cosmid libraries and development of STSs from cosmids mapped by FISH. Genomics 17: 682-693.

Renault, B., A. Hovnanian, S. Bryce, J.-J. Chang, S. Lau, A. Sakuntabhai, S. Monk, S. Carter, C.D.J. Ross, J. Pang et al. 1997. A sequence-ready physical map of a region of 12q24.1. Genomics 45: $271-278$.
Rodriguez, E., S. Mathew, V. Reuter, D.H. Ilson, G.J. Bosl, and R.S.K. Chaganti. 1992. Cytogenetic analysis of 124 prospectively ascertained male germ cell tumors. Cancer Res. 52: 2285-2291. Samaniego, F., E. Rodriguez, J. Houldsworth, V.V.V.S. Murty, M. Ladanyi, K.P. Lele, Q. Chen, E. Dmitrovsky, N.L. Geller, V. Reuter et al. 1990. Cytogenetic and molecular analysis of human male germ cell tumors: Chromosome 12 abnormalities and gene amplification. Genes Chromosomes Cancer 1: 289-300.

Schneider, B.G., D.R. Pulitzer, R.D. Brown, T.J. Prihoda, D.G. Bostwick, V. Saldivar, H.A. Rodriguez-Martinez, M.E.C. Gutierrez-Diaz, and P. O'Connel. 1995. Allelic imbalance in gastric cancer: An affected site on chromosome arm 3p. Genes Chromosomes Cancer 13: 263-271.

Schuler, G.D., M.S. Boguski, E.A. Stewart, L.D. Stein, G. Gyapay, K. Rice, R.E. White, P. Rodriguez-Tome, A. Aggarwal, E. Bajorek et al. 1996. A gene map of the human genome. Science 274: 540-546.

Seymour, A., R.H. Hruban, M. Redston, C. Caldas, S.M. Powell, K.W Kinzler, C.J. Yeo, and S.E. Kern. 1994. Allelotype of pancreatic adenocarcinoma. Cancer Res. 54: 2761-2764.

Stewart, E.A., K.B. McKusick, A. Aggarwal, E. Bajorek, S. Brady, A. Chu, N. Fang, D. Hadley, M. Harris, S. Hussain et al. 1997. An STS-based radiation hybrid map of the human genome. Genome Res. 7: 422-433.

Suchi, M., H. Sano, H. Mizuno, and Y. Wada. 1995. Molecular cloning and structural characterization of the human histidase gene (HAL). Genomics 29: 98-104.

Weissenbach, J., G. Gyapay, C. Dib, A. Vignal, J. Morissette, P. Millasseau, G. Vaysseix, and M. Lathrop. 1992. A second-generation linkage map of the human genome. Nature 359: 794-801.

Zou, H., W.J. Henzel, X. Liu, A. Lutschg, and X. Wang. 1997. Apaf-1, a human protein homologous to C. elegans CED-4, participates in cytochrome c-dependent activation of caspase-3. Cell 90: $405-413$.

Received March 10, 1999; accepted in revised form May 18, 1999.
Genome Research www.genome.org 


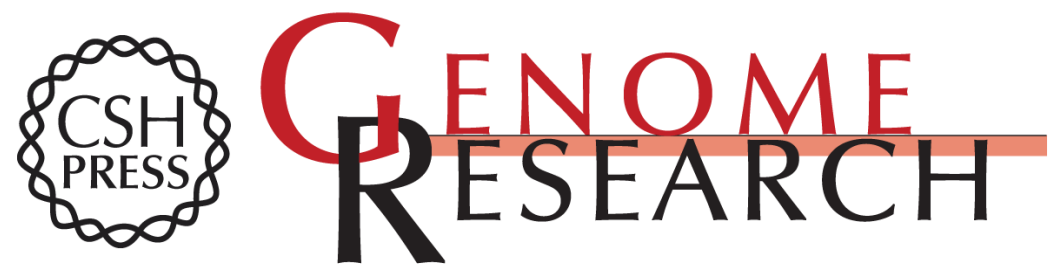

\section{A 3-Mb High-Resolution BAC/PAC Contig of 12q22 Encompassing the 830-kb Consensus Minimal Deletion in Male Germ Cell Tumors}

Vundavalli V.V.S. Murty, Kate Montgomery, Shipra Dutta, et al.

Genome Res. 1999 9: 662-671

Access the most recent version at doi:10.1101/gr.9.7.662

References This article cites 28 articles, 9 of which can be accessed free at:

http://genome.cshlp.org/content/9/7/662.full.html\#ref-list-1

\section{License}

Email Alerting Receive free email alerts when new articles cite this article - sign up in the box at the Service top right corner of the article or click here.

\section{Affordable, Accurate Sequencing.}

